\title{
Interleukin-35 inhibited the production of histamine and pro-inflammatory cytokines through suppression MAPKs pathway in HMC-1 cells
}

\author{
Li-xin $\mathrm{Fu}^{1 \dagger}$, Tao Chen ${ }^{1,2 \dagger}$, Qiao-mei Sun ${ }^{1}$, Pei-mei Zhou ${ }^{1}$ and Zai-pei Guo ${ }^{3^{*}}$ (1)
}

\begin{abstract}
Background: IL-35 is a newly anti-inflammatory cytokine that belongs to the IL-12 family. Mast cells, as one of the major effector cells in the immune response system, plays an important role in the pathogenesis of chronic spontaneous urticarial (CSU). Our study aims to explore the inhibited role of IL-35 in HMC-1.

Methods: The effects of IL-35 on cell proliferation, cytokine expression, and histamine release in a human mast cell line (HMC1) were investigated by CCK8, ELISA, or RT-PCR. The phosphorylation levels of ERK1/2, p38, and JNK1/2, in PMA plus A23187 induced HMC-1 cells was detected by Western Blot.

Results: We found that IL-35 significantly inhibited the proliferation of HMC-1 cells stimulated by PMA and A23187. IL-35 also down-regulates the release of histamine and the mRNA expression of IL-6 and IL-17 in activated HMC-1. Furthermore, IL-35 markedly inhibited the phosphorylation levels of ERK1/2, p38, and JNK1/2, in PMA plus A23187 induced HMC-1 cells.

Conclusions: This study provides the first observations on the inhibitory and anti-inflammatory effect of IL-35 in activated HMC-1 cells. We suggest that IL35 may play an inhibited role in the pathogenesis of CSU.
\end{abstract}

Keywords: Interleukin-(IL)35, Mast cells, Histamine, Anti-inflammatory effect, MAPK

\section{Background}

Chronic spontaneous urticarial (CSU), a mast cell-driven disease, is defined as the spontaneous appearance of weals, angioedema or both for $>6$ weeks for unknown or known causes [1]. Mast cells, as one of the major effector cells in the immune response system, plays an important role in the pathogenesis of CSU [2]. Although several studies had indicated that activated mast cells could release histamine and other cytokines, such as

\footnotetext{
*Correspondence: guozp930@163.com

${ }^{\dagger} \mathrm{Li}$-xin Fu and Tao Chen contributed equally to this work

${ }^{3}$ Department of Dermatovenereology, West China Hospital of Sichuan University, No. 37, Guoxue Alley, Chengdu 610041, Sichuan, China

Full list of author information is available at the end of the article
}

interleukin-6 (IL-6), tumor necrosis factor (TNF)- $\alpha$ or vascular endothelial growth factor (VEGF), which could be involved in inducing or developing CSU symptoms [3, 4]. However, the actual pathogenesis of CSU is not yet clear.

IL-35 is a newly anti-inflammatory cytokine that belongs to the IL-12 family and is composed of two subunits: Epstein-Barr virus-induced gene 3 (EBI3) and IL-12p35 [5]. Collison et al. have found that IL-35 signals through a unique heterodimer or homodimers receptor of IL-12R- $\beta 2$ and gp130 or each chain [6]. IL-35 is widely recognized as a definite immune suppressor with a huge potential for suppression. Tregs are the main resources for IL-35 secretion [7]. Abundant evidence had indicated

(c) The Author(s) 2021. This article is licensed under a Creative Commons Attribution 4.0 International License, which permits use, sharing, adaptation, distribution and reproduction in any medium or format, as long as you give appropriate credit to the original author(s) and the source, provide a link to the Creative Commons licence, and indicate if changes were made. The images or other third party material in this article are included in the article's Creative Commons licence, unless indicated otherwise in a credit line to the material. If material is not included in the article's Creative Commons licence and your intended use is not permitted by statutory regulation or exceeds the permitted use, you will need to obtain permission directly from the copyright holder. To view a copy of this licence, visit http://creativecommons.org/licenses/by/4.0/. The Creative Commons Public Domain Dedication waiver (http://creativecommons.org/ publicdomain/zero/1.0/) applies to the data made available in this article, unless otherwise stated in a credit line to the data. 
that IL-35 could suppress the activities of Th1 and Th17 cells and plays a crucial role in the pathogenesis of many types of autoimmune diseases, such as inflammatory bowel disease (IBD) [8], rheumatoid arthritis (RA) [9], and systemic lupus erythematosus (SLE) [10]. IL-35 could inhibit experimental colitis [5] and dampen collageninduced arthritis (CIA) in DBA/1 mice via suppression of Th17 cells [11]. Collison et al. reported that IL-35 primarily inhibits T-cell proliferation and further amplify T-cell effects by inducing a regulatory population capable of suppressing immune responses via IL-35 [12]. However, the effects of IL-35 in the pathogenesis of CSU has not yet been elucidated.

In our previous study, we found the decreased IL-35 serum levels in CSU patients, and the serum IL-35 levels were significantly increased in CSU patients after conventional treatment [13]. Therefore, we suggest that IL-35 may serve as anti-inflammatory cytokines, and play a role in the pathogenesis of CSU. To explore the role of IL-35 in the pathogenic mechanism of CSU, this study investigated the inhibited effects of IL-35 on phorbol 12-myristate 13-acetate (PMA) plus A23187 (calcium ionophore)-stimulated human mast cell line (HMC-1) cells.

\section{Materials and methods}

\section{Cell culture and stimulation}

The HMC-1 cells were purchased from EK-Bioscience of Shanghai company and cultured in IMDM with $100 \mathrm{U} /$ $\mathrm{ml}$ of penicillin and streptomycin, and $10 \%$ fetal bovine serum (FBS) at $37{ }^{\circ} \mathrm{C}$ in $5 \% \mathrm{CO}_{2}$. The $\mathrm{HMC} 1$ cells were treated with recombinant human IL-35 (1-1000 ng/ml) for $6 \mathrm{~h}$. The cells were then stimulated with $50 \mathrm{nM}$ of PMA plus $1 \mu \mathrm{M}$ of $\mathrm{A} 23187$ and incubated at $37{ }^{\circ} \mathrm{C}$ for the indicated periods ( $15 \mathrm{~min}-8 \mathrm{~h}$ ).

\section{Assay for the receptor of IL-35 (IL-12R- $\beta 2$ and gp130)}

The DNA was isolated from HMC-1 cells using DNA Reagent Kit (Tiangen Biological Manufacture Co. Ltd., Beijing, China). The primers for IL-12R- $\beta 2$ and gp130 were designed by ourselves. The forward primer sequence for IL-12R- $\beta 2$ was 5 -AGAGGCGATGTGACT GTGAA- $3^{\prime}$. The reverse primer sequence for IL-12R- $\beta 2$ was $5^{\prime}$-TCAGGGGTGAGGTTGATTCC- $3^{\prime}$. The forward primer sequence for gp130 was 5'-CCAGTGGTC ACCTCACACTC-3'. The reverse primer sequence for gp130 was $5^{\prime}$-GGGCAAAATACCATCACCGC-3'. The conditions were $94{ }^{\circ} \mathrm{C}$ for $90 \mathrm{~s}$, and $94{ }^{\circ} \mathrm{C}$ for $30 \mathrm{~s}$ and $55{ }^{\circ} \mathrm{C}$ for $30 \mathrm{~s}$ of 35 cycles with an extension at $72{ }^{\circ} \mathrm{C}$ for $5 \mathrm{~min}$.

The total protein samples of HMC-1 cells were extracted. Protein samples of $40 \mu \mathrm{g}$ were electrophoresed on $6 \%$ Tris-glycine gels, subjected to sodium dodecyl sulfate-polyacrylamide gel electrophoresis, and transferred to polyvinylidene fluoride membranes. Subsequently, membranes were incubated with primary antibody (IL-12R- $\beta 2$ and gp130) at $4{ }^{\circ} \mathrm{C}$ overnight and with the appropriate horseradish peroxidaseconjugated secondary antibody for $1 \mathrm{~h}$. The expression of IL-12R- $\beta 2$ and gp130 was determined with enhanced chemiluminescence reagents and exposure to a Kodak $\mathrm{x}$-ray film (Eastman Kodak, Rochester, New York).

\section{Cell viability}

Cell Counting Kit-8 (CCK8, WST, China) was used for cell viability assay. Firstly, HMC-1 cells were seeded in a 96-wells plate at the density of 103 cells/well in $100 \mu \mathrm{l}$ medium. Cells were treated with recombinant human IL-35 $(1,10,100,1000 \mathrm{ng} / \mathrm{ml})$ for $6 \mathrm{~h}$ at the beginning of the test and cell viabilities were determined. In addition, cells were treated with different concentrations of IL-35 $(1,10,50,100,1000 \mathrm{ng} / \mathrm{ml})$ for $6 \mathrm{~h}$ before stimulation with $50 \mathrm{nM}$ of PMA plus $1 \mu \mathrm{M}$ of A23187 and incubated at $37^{\circ} \mathrm{C}$ for $8 \mathrm{~h}$. And then $10 \mu \mathrm{lCCK} 8$ was added to each well and incubated for $1 \mathrm{~h}$, and the optical density (OD) value was determined by a microplate reader at $450 \mathrm{~nm}$.

\section{Histamine assay}

Histamine levels from HMC-1 cells were determined using Human Histamine Elisa Assay Kit (Nanjing Jiancheng Bioengineering Institute, Nanjing, China) following the manufacturer's instruction. The optical density (OD) was determined at $450 \mathrm{~nm}$ in a microplate reader. The histamine release is present as a percentage of total $[$ released/(intracellular + released) $] \times 100 \%$.

\section{Real-time quantitative PCR}

HMC-1 cells were seeded in a 6-wells plate and then treated with recombinant human IL-35 (50 and $100 \mathrm{ng} /$ $\mathrm{ml}$ ) for $6 \mathrm{~h}$ before stimulation with $50 \mathrm{nM}$ of PMA plus $1 \mu \mathrm{M}$ of A23187 and incubated at $37{ }^{\circ} \mathrm{C}$ for $8 \mathrm{~h}$. The mRNA levels of IL-4, IL-6, IL-17, IFN- $\gamma$, and TNF- $\alpha$ in HMC-1 cells from different groups were determined by real-time quantitative PCR. Total RNA was extracted by Trizol reagent (Invitrogen Corp, Carlsbad, CA, USA) according to the manufacturer's instructions. The cDNA was synthesized from the total RNA by using RT reagent Kit with gDNA Eraser (Takara, Dalian, China). cDNA samples were amplified in a $20 \mu \mathrm{l}$ reaction volume containing $10 \mu \mathrm{l}$ of $2 \times$ SYBR GreenMaster Mix (Takara, Dalian, China), $2 \mu \mathrm{l}$ of cDNA and $0.25 \mu \mathrm{M}$ qPCR primers. The following primers were used: IL-4 (P216616, Bioneer, Inc., Daejeon, Korea); IL-6 (P211161, Bioneer, Inc., Daejeon, Korea); IL-17 (P291322, Bioneer, Inc., Daejeon, Korea); INF- $\gamma$ (Catalog: HQP009467, GeneCopoeia, USA); TNF- $\alpha$ (P237423, Bioneer, Inc., Daejeon, Korea); 
GAPDH (5'-CGGAGTCAACGGATTTGGTC- ${ }^{\prime}$ and $5^{\prime}$-CGGTGCCATGGAATTTGCCA-3'). The conditions were $95{ }^{\circ} \mathrm{C}$ for $5 \mathrm{~min}$, and $95{ }^{\circ} \mathrm{C}$ for $15 \mathrm{~s}$ and $60{ }^{\circ} \mathrm{C}$ for $30 \mathrm{~s}$ of 40 cycles with a final extension at $72{ }^{\circ} \mathrm{C}$ for $5 \mathrm{~min}$. The mRNA levels of IL-17 and IL-6were expressed as relative mRNA levels compared with control and determined by the $2^{-\Delta \Delta \mathrm{Ct}}$ method.

\section{Western blot analysis}

The expression of mitogen-activated protein kinases (MAPKs) in HMC-1 cells was measured by western blot. HMC-1 cells were treated with recombinant human IL-35(50 and $100 \mathrm{ng} / \mathrm{ml})$ for $6 \mathrm{~h}$ before stimulation with $50 \mathrm{nM}$ of PMA plus $1 \mu \mathrm{M}$ of A23187 and incubated at $37^{\circ} \mathrm{C}$ for $15 \mathrm{~min}$. After treatment, cells were collected and lysed in ice-cold RIPA buffer (EMD Millipore, Billerica, Massachusetts) containing $1 \%$ phenylmethylsulfonyl fluoride. The samples were vortex mixed for lysis for a few seconds every $15 \mathrm{~min}$ at $4{ }^{\circ} \mathrm{C}$ for $1 \mathrm{~h}$ and centrifuged at $13,000 \mathrm{rpm}$ for $50 \mathrm{~min}$ at $4{ }^{\circ} \mathrm{C}$. Then, the samples were heated at $98{ }^{\circ} \mathrm{C}$ for $10 \mathrm{~min}$ and briefly cooled on ice. Then, the total protein was extracted. Protein samples of $40 \mu \mathrm{g}$ were electrophoresed on $12 \%$ Tris-glycine gels, subjected to sodium dodecyl sulfate-polyacrylamide gel electrophoresis, and transferred to polyvinylidene fluoride membranes. Subsequently, membranes were incubated with primary antibody at $4{ }^{\circ} \mathrm{C}$ overnight and with the appropriate horseradish peroxidase-conjugated secondary antibody for $1 \mathrm{~h}$. The expression of MAPKs was determined with enhanced chemiluminescence reagents and exposure to a Kodak $\mathrm{x}$-ray film (Eastman Kodak, Rochester, New York). The results were normalized to the expression of $\beta$-actin.

\section{Statistical analysis}

All data were expressed as mean $\pm \mathrm{SD}$. One-way analysis of variance, Mann-Whitney U Test or Wilcoxon signrank test were used to compare statistical differences between groups. Each experiment was carried out at least 3 times. $\mathrm{P}<0.05$ was set as statistically significant.

\section{Results}

IL-35 receptor IL-12R- $\beta 2$ and gp130 are expressed in HMC- 1 cells

To better establish the relevance of the IL-35 pathway in CSU, we investigated the direct expression of IL-35 receptor IL-12R- $\beta 2$ and gp130 in HMC-1. By PCR and western blot analysis, we established the expression of IL-12R- $\beta 2$ and gp130 in HMC-1 (Fig. 1).

\section{Regulatory effect of IL-35 on the proliferation of HMC-1 \\ cells}

First of all, the cytotoxicity of IL-35 was evaluated using CCK8 assay, and IL-35 was found not to affect HMC-1 cell viability at concentrations of 1 to $1000 \mathrm{ng} / \mathrm{ml}$ (Fig. 2a). After that, we clarified whether IL-35 could regulate mast cell proliferation stimulated by PMA and A23187. As shown in Fig. 2b, IL-35, at a concentration of $100 \mathrm{ng} / \mathrm{ml}$, significantly inhibited the HMC-1 cell viability stimulated by PMA and A23187.

\section{IL-35 inhibited the histamine releases in HMC-1 stimulated} by PMA and A23187

To explore the role of IL-35 in the HMC-1, we detected the release of histamine in HMC-1 stimulated by PMA and A23187. As presented in Fig. 3, IL-35 significantly inhibited the histamine releases in $\mathrm{HMC}-1$ stimulated

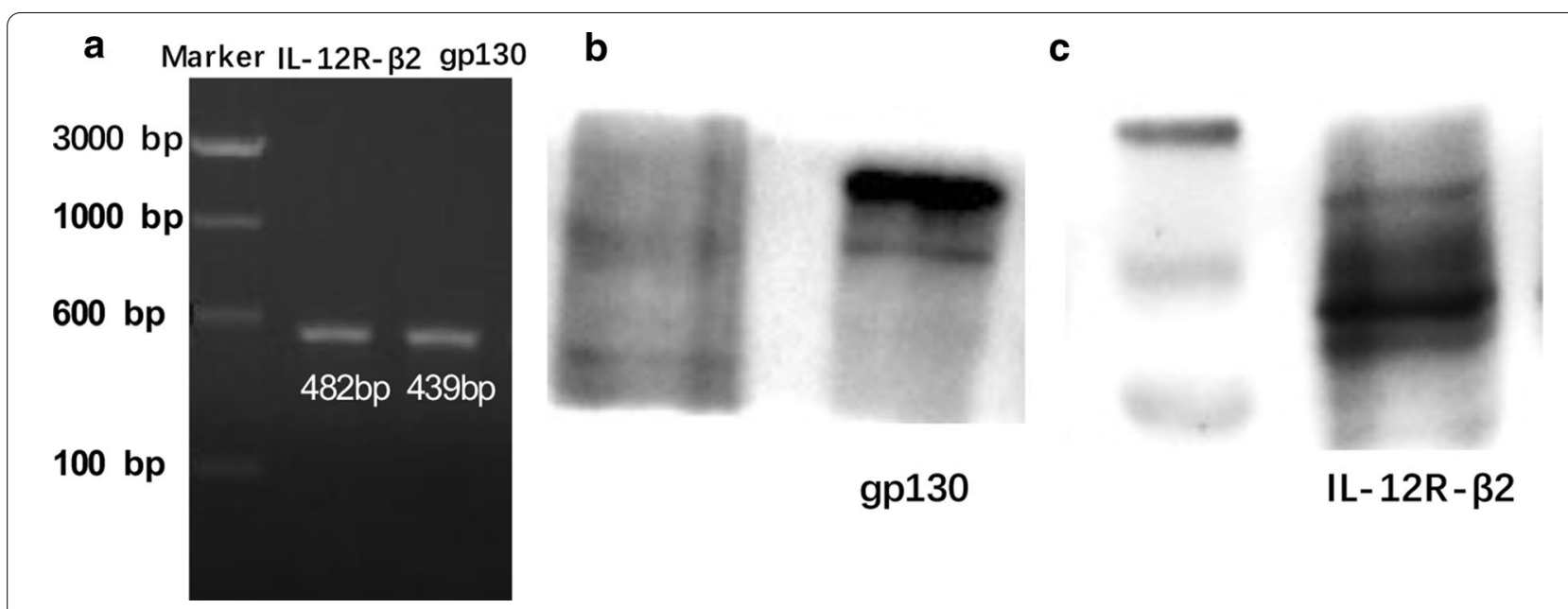

Fig. 1 IL-35 receptor IL-12R- $\beta 2$ and gp130are expressed in HEC-1 cells. a The direct expression of IL-35 receptor IL-12R- $\beta 2$ and gp130 inHMC-1 were detected by PCR. $\mathbf{b}, \mathbf{c}$ The expression of IL-35 receptor IL-12R- $\beta 2$ and gp130 inHMC-1 were detected by western blot 

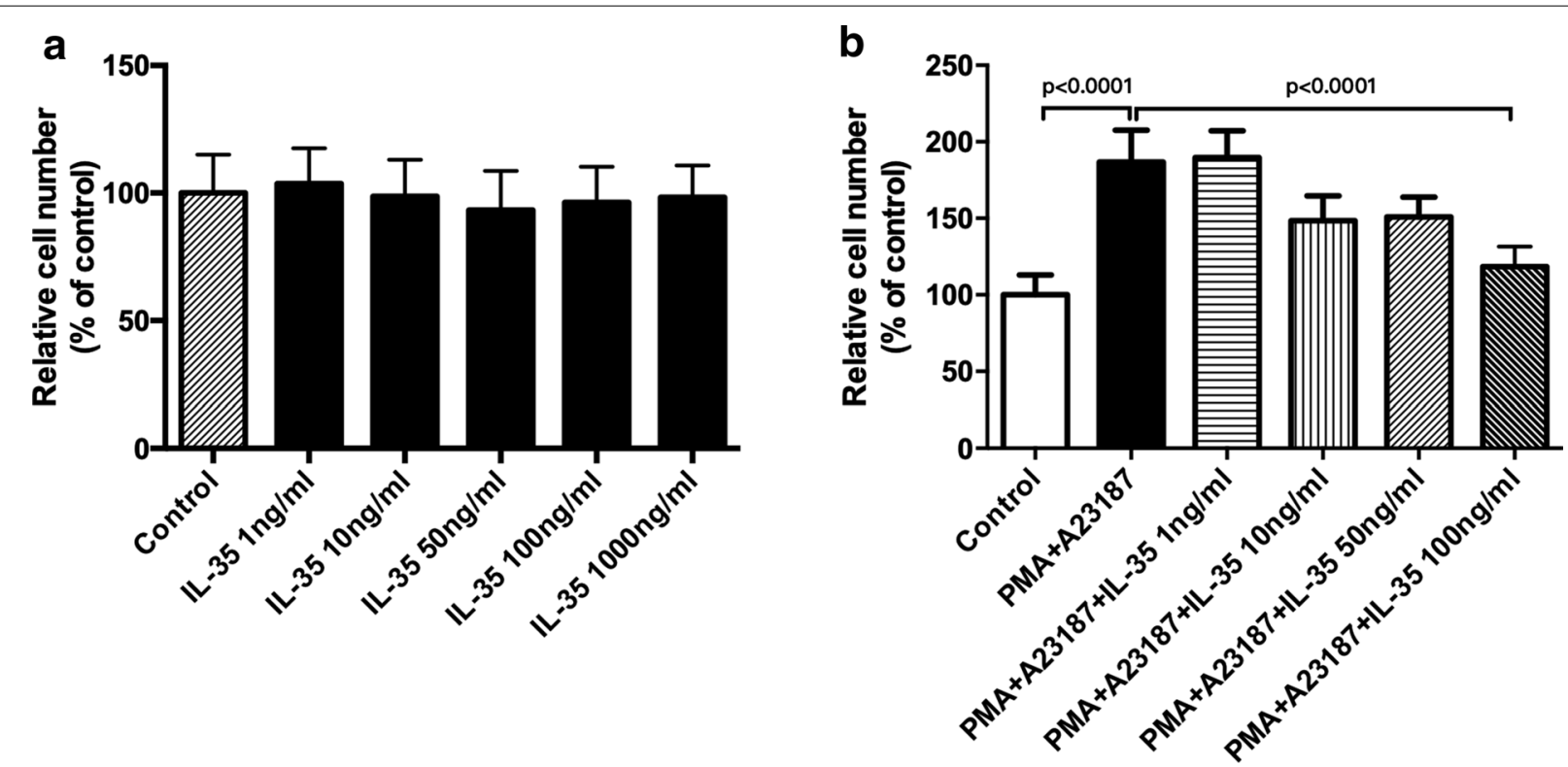

Fig. 2 Regulatory effect of IL-35 on the proliferation of HMC-1 cells. a HMC-1 cells were treated with IL-35 (1-1000 ng/ml) for 6 h. Cell viability was measured by CCK8. b HMC-1 cells were treated with IL-35 (1-100 ng/ml) for $6 \mathrm{~h}$ and stimulated with PMA (50 nM) plus A23187 (1 $\mu$ M) for 8 h. Cell viability was measured by CCK8. All data are expressed as mean \pm SD. P values are based on the One-way analysis of variance. $n=10$

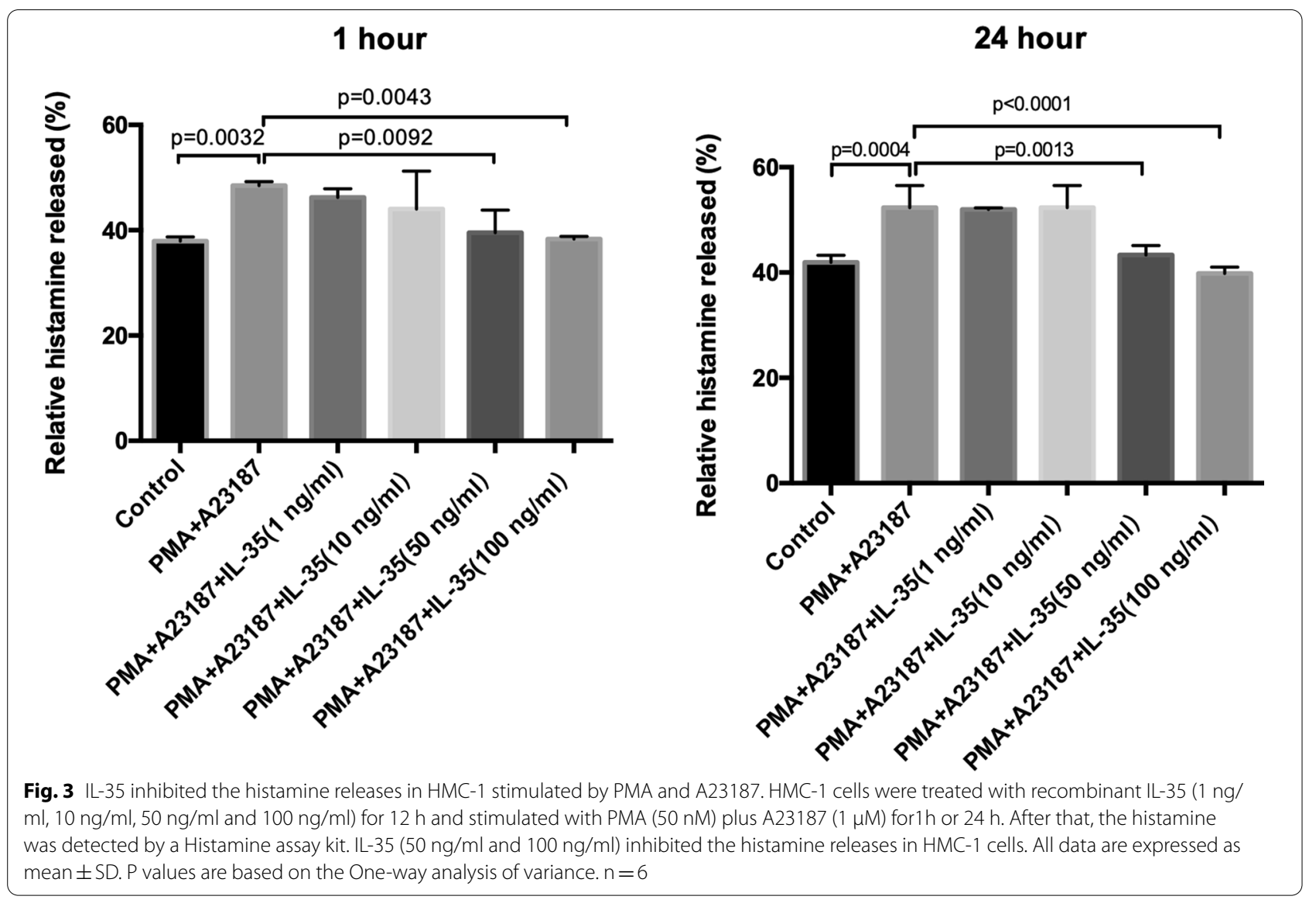


by PMA and A23187 when compared with PMA plus A23187 controls.

\section{IL-35 down-regulates the mRNA expression of IL-6 and IL-17 in HMC-1 stimulated by PMA and A23187}

To explore the role of IL-35 in the HMC-1, we also assayed cytokines mRNA expression (including IL-4, IL-6, IL-17, IFN- $\gamma$, and TNF- $\alpha$ ) in HMC- 1 stimulated by PMA and A23187. As presented in Fig. 4, IL-35 caused a markedly decrease in the mRNA levels of IL-6 and IL-17 in HMC-1 stimulated by PMA and A23187 when compared with controls. However, the mRNA expression of IL-4, IFN- $\gamma$, and TNF- $\alpha$ in simulated HMC-1 showed no difference between the groups with or without IL-35 treatment.

\section{Effects of IL-35 on activation of MAPKs}

To evaluate the mechanisms underlying the effects of IL-35, we examined the potential effects of IL-35 on the activation of MAPKs. The phosphorylation levels of p38, JNK, and ERK were increased after HMC-1 cells treated with PMA plus A23187. As shown in Fig. 5, IL-35 attenuated PMA plus A23187-induced phosphorylation levels of all three types of MAPKs.

\section{Discussion}

IL-35, a novel anti-inflammatory cytokine, is composed of two subunits: EBI3 and IL-12p35 [5]. Previous studies have shown that IL-35 could perform anti-inflammatory and immunosuppressive actions in many autoimmunity diseases and models. Ouyang et al. have found that serum levels of IL-35 and the percentage of CD4+EBI3+ T cells were markedly decreased in patients with active SLE compared with patients with inactive SLE and healthy

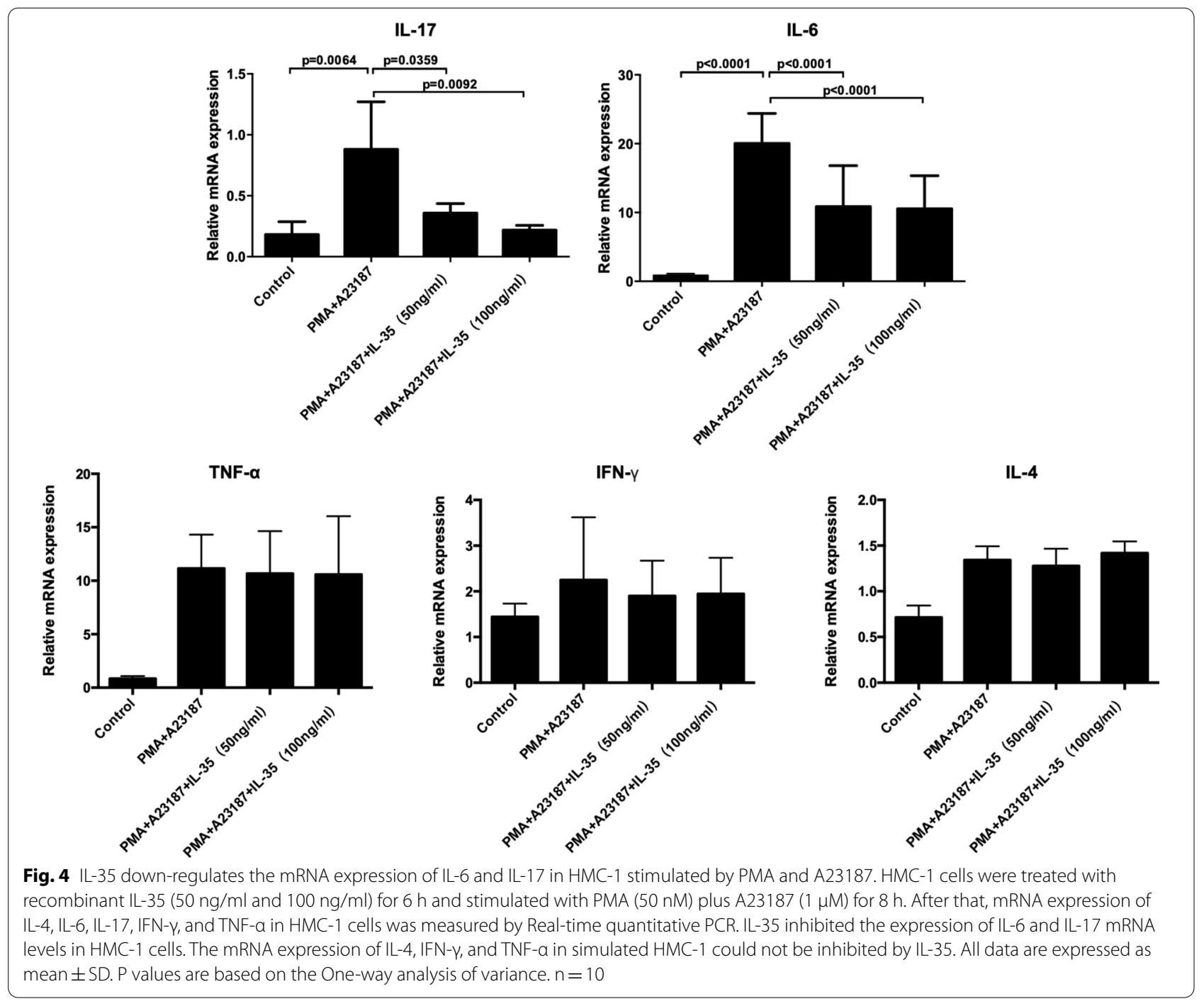




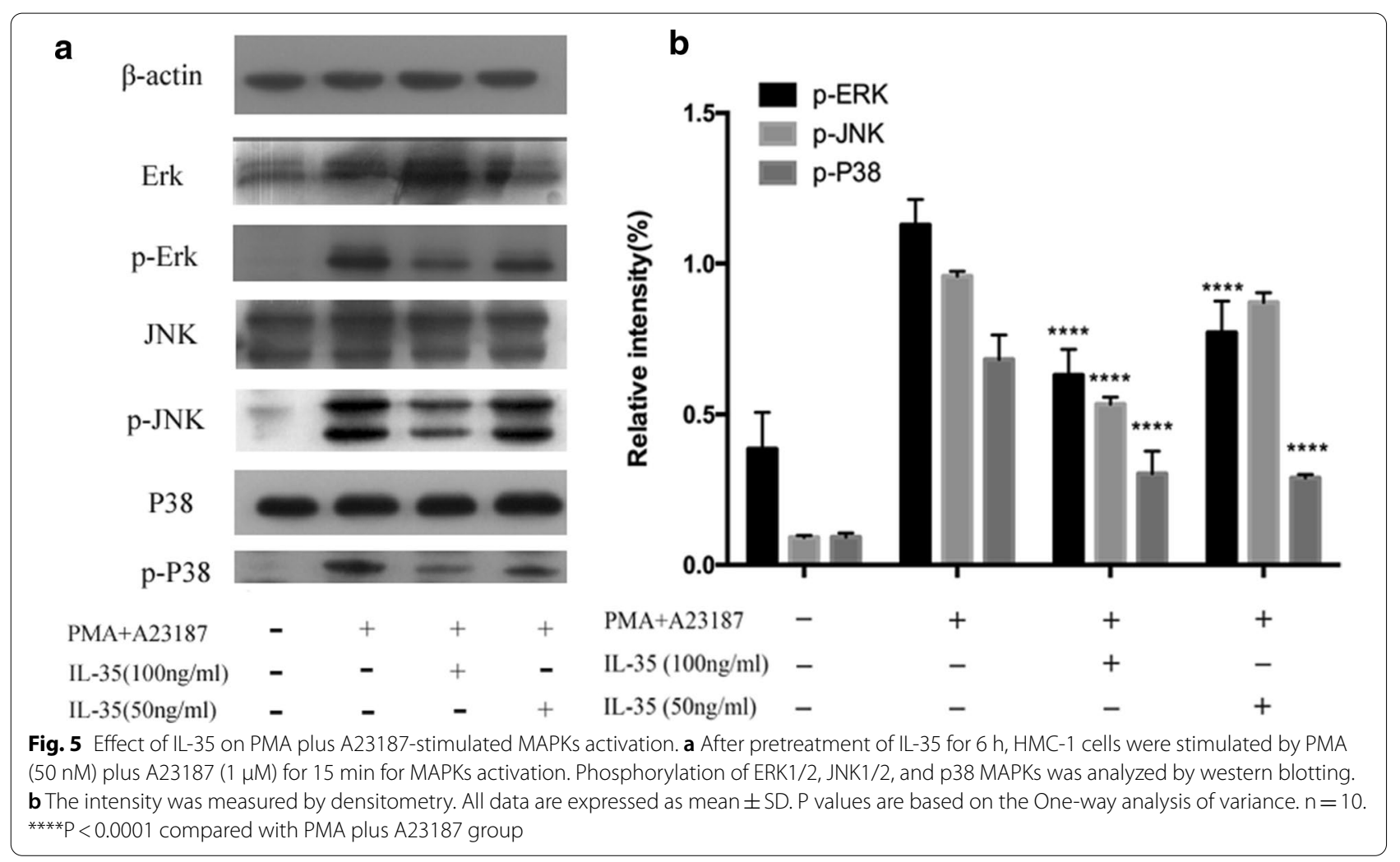

controls [10]. Niedbala et al. reported that IL-35 can inhibit the development of RA through the suppression of Th17 cells and expansion of Treg cells [11]. IL-35 has also been evaluated the activity of anti-inflammatory in an inflammatory bowel diseases model by reducing colonic gene expression of pro-inflammatory cytokines and Th1/Th17-associated transcription factors [5, 12, 14]. Our previous study also reported that the serum IL-35 levels were significantly decreased in patients with CSU compared with healthy controls and CSU patients after conventional treatment, and indicated that the reduction of IL-35 levels may play an important role in the pathogenesis of CSU [13].

Mast cells, as one of the major effector cells in the immune response system, are the major primary effector cell type in diseases of immediate hypersensitivity [15], including urticarial and angioedema. Mast cells are activated during the immediate IgE-mediated allergic response [16]. Some pro-inflammatory cytokine, such as TNF- $\alpha$, IL- 6 , and IL- 8 could be derived by activated mast cells and had critical biological roles in the pathogenesis of CSU [4]. Inflammatory cytokines are important factors in chronic inflammation, urticarial, allergy, asthma, and autoimmune diseases. Mast cells play an integral role in the inflammatory response by accumulating at sites of inflammation and mediating the production of inflammatory cytokines, such as IL-6 and IL-8 [17]. In this study, the inhibitory effect of IL-35 on the HMC-1 proliferation is determined by CCK8. The results showed that IL-35 could not affect HMC-1 cell viability at different concentrations. However, IL-35, at a concentration of $100 \mathrm{ng} / \mathrm{ml}$, significantly inhibited the HMC-1 cell proliferation induced by PMA and A23187. Activated mast cells release inflammatory mediators including tryptase, histamine, heparin, leukotrienes, and prostaglandins. Mast cells also express the proinflammatory cytokine of IL-4, IL-5, IL-6, IL-8, IL-13, and TNF- $\alpha$ [18]. Previous studies have indicated that the reduction of pro-inflammatory cytokine from mast cells is one of the key indicators of reduced inflammatory symptoms [19]. The present study also examined the inhibitory effect of IL-35 on the production of IL-4, IL-6, IL-17, IFN- $\gamma$, and TNF- $\alpha$ in HMC-1 cells activated by PMA plus A23187, as these cytokines have powerful inflammatory effects and are released by activated mast cells. As shown in Figs. 3 and 4, IL-35 inhibited the release of histamine and the gene expression of inflammatory cytokines, IL-6 and IL-17 production in HMC-1 cells stimulated with PMA plus A23187 by RT-PCR analysis. Moreover, the mRNA expression of IL-4, IFN- $\gamma$, and TNF- $\alpha$ in simulated HMC- 1 could not be inhibited by IL-35. Therefore, these data implied that 
IL-35 exerts markedly inhibited the proliferation and the antiinflammatory effects in PMA plus A23187-stimulated HMC-1.

MAPKs belong to a family of proline-directed serine/ threonine protein kinases that play an important signaling pathway in immune responses [20]. Three major factors, ERKs, p38, and stress-activated protein kinases (SAPKs)/JNK [17], that mediate the MAPK pathways have been identified in mammals. Although the precise signaling pathways among ERK, JNK, and p38 are still unclear. It has been reported that ERK, p38, and JNK are activated in response to extracellular stimuli and perform different functions, including mediation of apoptosis, proliferation, and inflammation [21]. To explore the mechanism involved in the inhibitory and anti-inflammatory effect of IL-35in HMC-1, we investigated the activation of three members (ERK, p38, and JNK) of MAPKs on PMA plus A23187-stimulated HMC-1 cells. Results of the current study demonstrated that the activities of three members (ERK, p38, and JNK) of MAPKs were increased by PMA plus A23187, and that IL-35 significantly inhibited the phosphorylation levels of ERK1/2, p38, and JNK1/2, in PMA and A23187 induced HMC-1 cells. All the above data suggested that IL-35 inhibited the proliferation and exerted antiinflammatory effects by decreases IL- 6 and IL-17 production in PMA plus A23187-stimulated HMC-1 via the inhibition of ERK1/2, p38, and JNK1/2 activation.

To summarize our results, this study provides the first observations on the inhibitory role of IL-35 in HMC-1 cells. IL-35 significantly inhibited the proliferation and the production of histamine, IL-6, and IL-17 in PMA plus A23187-stimulated HMC-1 cells. Furthermore, IL-35 inhibited the ERK1/2, p38, and JNK1/2 pathways. Therefore, we suggest that IL-35 may serve as anti-inflammatory cytokines, and play a role in the pathogenesis of CSU.

\begin{abstract}
Abbreviations
CSU: Chronic spontaneous urticarial; IL: Interleukin; EBI3: Epstein-Barr virusinduced gene 3; IBD: Inflammatory bowel disease; RA: Rheumatoid arthritis; SLE: Systemic lupus erythematosus; CIA: Collagen-induced arthritis; AD: Atopic dermatitis; HMC-1: Human mast cell line; PMA: Phorbol 12-myristate 13-acetate; ELISA: Enzyme-linked immunosorbent assay; MAPKs: Mitogenactivated protein kinases.
\end{abstract}

\section{Acknowledgements}

Not applicable.

\section{Authors' contributions}

Concept, design, definition of intellectual content: LF, TC and ZG; literature search: LF and QS; experiment studies: LF and QS; data acquisition and data analysis: QS and PZ; manuscript preparation: LF and TC; manuscript editing: LF and TC; manuscript review: ZG. All authors read and approved the final manuscript.

\section{Funding}

The study was supported by the Health and Family Planning Commission of Sichuan Provincial (2019YJ0627).

Availability of data and materials

All data generated or analyzed during this study are included in this published article.

\section{Declarations}

Ethics approval and consent to participate

Not applicable.

\section{Consent for publication}

Not applicable.

\section{Competing interests}

The authors declare no conflict of interest.

\section{Author details \\ ${ }^{1}$ Department of Dermatovenereology, Chengdu Second People's Hospital, Chengdu 610017, Sichuan, China. ${ }^{2}$ Department of Dermatovenereology, Chengdu Qingbaijiang Distinct People's Hospital, Chengdu 610300, Sichuan, China. ${ }^{3}$ Department of Dermatovenereology, West China Hospital of Sichuan University, No. 37, Guoxue Alley, Chengdu 610041, Sichuan, China.}

Received: 7 July 2020 Accepted: 5 April 2021

Published online: 17 April 2021

\section{References}

1. Zuberbier T, Aberer W, Asero R, et al. The EAACI/GA(2) LEN/EDF/WAO guideline for the definition, classification, diagnosis, and management of urticaria: the 2013 revision and update. Allergy. 2014;69:868-87.

2. Mekori YA, Metcalfe DD. Mast cells in innate immunity. Immunol Rev. 2000;173:131-40.

3. Barnes PJ, Adcock I. Anti-inflammatory actions of steroids: molecular mechanisms. Trends Pharmacol Sci. 1993;14:436-41.

4. Church MK, Levi-Schaffer F. The human mast cell. J Allergy Clin Immunol. 1997;99:155-60.

5. Collison LW, Workman CJ, Kuo TT, et al. The inhibitory cytokine IL-35 contributes to regulatory T-cell function. Nature. 2007;450:566-9.

6. Collison LW, Delgoffe GM, Guy CS, et al. The composition and signaling of the IL-35 receptor are unconventional. Nat Immunol. 2012;13:290-9.

7. Chaturvedi V, Collison LW, Guy CS, et al. Cutting edge: human regulatory T cells require IL-35 to mediate suppression and infectious tolerance. J Immunol. 2011;186:6661-6.

8. Fonseca-Camarillo G, Furuzawa-Carballeda J, Yamamoto-Furusho JK. Interleukin 35 (IL-35) and IL-37: intestinal and peripheral expression by $T$ and $B$ regulatory cells in patients with inflammatory bowel disease. Cytokine. 2015;75:389-402.

9. Nakano S, Morimoto S, Suzuki S, et al. Immunoregulatory role of IL-35 in T cells of patients with rheumatoid arthritis. Rheumatology. 2015:54:1498-506.

10. Ouyang H, Shi YB, Liu ZC, et al. Decreased interleukin 35 and CD4+EBI3+ $T$ cells in patients with active systemic lupus erythematosus. Am J Med Sci. 2014;348:156-61.

11. Niedbala W, Wei XQ, Cai B, et al. IL-35 is a novel cytokine with therapeutic effects against collagen-induced arthritis through the expansion of regulatory $T$ cells and suppression of Th17 cells. Eur J Immunol. 2007:37:3021-9.

12. Collison LW, Chaturvedi V, Henderson AL, et al. IL-35-mediated induction of a potent regulatory T cell population. Nat Immunol. 2010;11:1093-101.

13. Chen T, Fu LX, Sun QM, et al. Decreased interleukin-35 serum levels in patients with chronic spontaneous urticaria. Ann Allergy Asthma Immunol. 2018;121:503-4. 
14. McLean MH, Neurath MF, Durum SK. Targeting interleukins for the treatment of inflammatory bowel disease - what lies beyond anti-TNF therapy? Inflamm Bowel Dis. 2014;20:389-97.

15. Schwartz LB. Mediators of human mast cells and human mast cell subsets. Ann Allergy. 1987;58:226-35.

16. Schwartz LB. Mast cells and their role in urticaria. J Am Acad Dermatol. 1991;25:190-203 (discussion 203-194)

17. Widmann C, Gibson S, Jarpe MB, et al. Mitogen-activated protein kinase: conservation of a three-kinase module from yeast to human. Physiol Rev. 1999;79:143-80.

18. Bradding P. Human mast cell cytokines. Clin Exp Allergy. 1996;26:13-9.

19. Kang OH, Choi JG, Lee JH, et al. Luteolin isolated from the flowers of Lonicera japonica suppresses inflammatory mediator release by blocking
NF-kappaB and MAPKs activation pathways in HMC-1 cells. Molecules. 2010;15:385-98.

20. Kawakami Y, Hartman SE, Holland PM, et al. Multiple signaling pathways for the activation of JNK in mast cells: involvement of Bruton's tyrosine kinase, protein kinase C, and JNK kinases, SEK1 and MKK7. J Immunol. 1998;161:1795-802.

21. Yamamoto $Y$, Yin MJ, Lin KM, et al. Sulindac inhibits activation of the NF-kappaB pathway. J Biol Chem. 1999;274:27307-14.

\section{Publisher's Note}

Springer Nature remains neutral with regard to jurisdictional claims in published maps and institutional affiliations.
Ready to submit your research? Choose BMC and benefit from:

- fast, convenient online submission

- thorough peer review by experienced researchers in your field

- rapid publication on acceptance

- support for research data, including large and complex data types

- gold Open Access which fosters wider collaboration and increased citations

- maximum visibility for your research: over 100M website views per year

At BMC, research is always in progress.

Learn more biomedcentral.com/submissions 